\title{
Art and Critique of PatriaLOGY: Montenegrin Women Poets and Their Presence/Absence in/from the Montenegrin Literary Context ${ }^{1}$ (I)
}

\author{
Dr. Aleksandra Nikčević-Batrićević
}

Department of English Language and Literature Faculty of Philosophy Nikšić, University of Montenegro

\section{Doi:10.5901/mjss.2014.v5n1p147}

\section{Abstract}

The aim of this paper is to reconsider the place of women poets in the Montenegrin literary context. In the introductory part of the paper, I will concentrate on Montenegrin history, the place of women within that historical context and their literary achievements that were rarely recorded in individual texts, books or literary histories. It was at the beginning of the last decade of the twentieth century that the revision of the Montenegrin literary canon was initiated, but it is itself incomplete in contributing to the full understanding of the literary accomplishments of women authors. I will offer a pattern, inspired by Elaine Showalter's work and other American theorists and critics, that can contribute to the demarginalization of the Montenegrin women poets and the appearance of objective critical texts about their works.

Keywords: marginalization, tradition, history, poetry, women poets.

Although the paper that I am presenting today has the title of "Art and Critique of PatriaLOGY: Montenegrin Women Poets and Their Presence/Absence in/from the Montenegrin Literary Context," in the process of preparing it, or my efforts to finalize it, a subtitle, or several of them, actually key points, were added, which I intend to deal with: what is the purpose of literary canons? who shapes them? do political elites shape literary canons? can we accept that a canon is a political issue which has to do with ideological apparatuses and not only with social norms, as Miško Šuvaković (2005) writes?; can the Anglo-American experience help in the mapping of female voices in the Montenegrin literary context, that is, in a more frequent and more thorough interpretation of their poetic accomplishments?; what can be done to ensure that female poetic voices are better heard?

An anthology of Montenegrin poetry (Rakočević, 2012) served as a direct reason to examine the place of women poets in literary canon, that old-fashioned word, as Dubravka Ugrešić (2012) called it, in which the editor, Bogić Rakočević, did not include women poets. In a review, published about the anthology, the critic Lidija Vukčević (2013) gives the following comments on the choice of poets brought together in this anthology: "We direct our only complaint to the editor because of the omission of female poetic voices. Even though they are present in lower numbers, especially in the second half and at the end of the century, we believe that the editor did this on purpose, leaving such a choice to another newer anthological palette of modern Montenegrin poetry."

I will answer the question of "what can be done to ensure that female poetic voices are better heard?" most thoroughly in this paper. Since this paper is the first step on my way into the world of the Montenegrin studies and female voices which have made and are still making their mark on the expression of this literature, I must first of all clarify the impulse that made me begin researching this issue: as Dubravka Đurić (2011) wrote in one text, I am acting as an anthropologist entering unknown regions with my own opinions and prejudices, formed on the basis of dealing with another type of literature: as a scholar of English and American literature, with a constant leaning towards poetry and a focus on female voices in Anglo-American literature, and as a theoretician inclined towards feminist literary theory, whose task it is "to affirm women writing" or "to affirm women authors whose work is ignored or undervalued," I was inspired to think about this issue by one aspect of this theory which changed the map of American literature during the 1970s and 1980 s and initiated a revision of the canon in many world, European and also even post-Yugoslav literatures. Just to remind you, during the last thirty years many studies have confirmed that women in various countries and epochs were writing diaries, poems and novels: poems of Buddhist monks, Sagami's poems about nature; the Parisian, Christine de Pizan, whom some regard as the initiator of feminist issues, because in her debates she pointed out elements of

\footnotetext{
1 This paper was presented at the conference held in the Montenegrin Academy of Sciences and Arts, in December 2011. The conference was organized by the Centre for Young Scientists at the Montenegrin Academy of Sciences and Arts.
} 
misogyny. In their introduction to Feminist Literary Theory and Criticism Gilbert and Gubar (2007) wrote that Pizan sought to build a Cite des dames - A City of Ladies - as the spirit of "Reason" whom she met in a vision commanded her to do, declaiming "Get up, daughter! Without waiting any longer, let us go to the Field of Letters. There the City of Ladies will be founded on a flat and fertile plain, where all fruits and freshwater rivers are found and where the earth abounds in all good things."

I must also add one subjective note to this text: at the start of the eighties I found out that there had been a Montenegrin Sappho (Sappho, the woman author on the island of Lesbos, who was imitated by poets like Horace and Catullus and wrote poetry from a personal point of view). Here is a short excerpt from a text published in the journal Jugoslavenski list (1940):

"The late Sara Niković, the Montenegrin Sappho, born in Nikšic in 1883, moved in respectable and chivalrous circles, and was inspired by nobility, gentleness and respectability, but her beauty, so valued amongst the bare rock of Montenegro, was known and heard of far and wide. As one Montenegrin poet writes, that beauty "astonished Montenegro and the seven hills" and it was said that "one such as her had not been born in three lifetimes of men" (...) After a severe blow in her life and a series of tragic deaths of those who were nearest and dearest to Sara, she began to wear black and to write poetry. The cycle of her poems, deep, emotional and gentle, place her alongside the best poets of her type."

Professor Nikola Knežević (also in Jugoslavenski list) published a beautiful article about the late poetess and these texts were inspiring enough to remind myself of the context in which the Montenegrin Sappho lived, and to ask the question: are there also other female poetic voices in Montenegrin literature which remain unmapped, neglected and undervalued? Just a consideration of the context, especially the chronological period between 1790 and 1915, about which, among other things, I had read in the chapters of the book Historical Reader: Women in Montenegro from 1790. to 1915., devoted to "our female forebears who are deleted from historical memory," (Nelević, 2011) which was published "with the intention of creating a starting point for various directions of research and interpretation, a book on the awareness of the current historical discussion in which women are barely visible, or are visible only as a patriarchal stereotype on the margins of memory," best sums up the story which is well known to scholars who have taken even a quick peek at the issues of sex, gender, feminism and the Beauvoirian idea that one is not born a woman, but becomes one. Following the statements in the aforementioned Reader which Nataša Nelević edited we can summarize the story about the historical context,

- in which the patriarchate is the politics of keeping power for men, while the woman is an inferior being who is destined 'by nature' for the role of mother and wife;

- in which the woman had to respect the rules in a world divided between the private (female, passive and subordinate) and public (male): "Wherever you look, you see a woman inclining her head towards a man," wrote Arsa Pajević, while Josef Jan Svátek described a small group of women "turning the spindle and talking quietly so as not to disturb the loud discussions of their husbands, their masters";

- $\quad$ in which the only woman heard in the public realm is the "lamenter." According to Rovinski, frequently quoted in the Historical Reader, "when she is alone, a woman simultaneous laments and creates the lament [...]" ... According to Nelević (2011), the woman who laments has afforded herself the right to articulate the values of the patriarchal world, to give moral judgments, but also to integrate political opinions into her laments which, as a unique aesthetic and ideological practice, during the entire $19^{\text {th }}$ and $20^{\text {th }}$ centuries remained the only opportunity for a woman to express herself publicly and draw the attention of the community to herself.

In the context of emphasizing the position of neglected and undervalued female voices in Montenegrin literary context, in which the absence of women poets from the anthologies is explained "by the reluctance of the patriarchal society and literary structure to allow their voices to be heard" (Đurić, 2011), Marinko Vorgić points out that new women poets left out registers of sentimental tones and motifs in their works at the end of the twentieth century, bringing into Montenegrin poetry a sensibility that it was lacking, a lyrical reflection on the individual and intimate, screening through the everyday, and a treatment of love:

"This sort of demarcation represents an important milestone in Montenegrin poetry, poetry which is slow-moving precisely due to the weight of great themes from which, in its epic inertia it was rarely freed during the 20th century. And just as great events have structured our mentality, so the poetic feel was carried off with disbelief towards all those motifs in which the aroma of the epoch and of grandeur was not sensed. Because of this a record without pretentiousness, through motifs and symbol which often come from the mundane and everyday is an essential strategy of these female writings." (2011) 
Confirming the existence of the demarcation "in the establishment of a new postmodern literary paradigm," Dubravka Đurić, in her text in which she maps the literary achievements in the post-Yugoslav states (in a chapter subtitled "Montenegrin Poetry: the Postmodern and Leaving Behind the Epic Poetic Paradigm"), quotes the critic Borislav Jovanović (2011) who wrote that "only with the postmodern are we leaving the many ancient relics of our spirit. Only with the postmodern and the application of its mechanism of deconstruction are we entering a new area of reading and writing the entire Montenegrin experience. Only through the postmodern have we reached some deep and standard forms of the modern. We are talking about a Montenegrin spiritual and aesthetic purification, or rather a break between $20^{\text {th }}$-century and third-millennium Montenegro."

\begin{abstract}
"All our theories since time immemorial have been epic. Not only were our theories of poetry (literature) epic, but also our theory of life, theory of death and theory of the future. Our theory of melancholy was also epic. Freedom from epic theories means separation from corruptible monogenous images of the world. In poetry that was broken through a cry for an elite, hieratic script instead of a vernacular, that is, demotic, one." (2011)
\end{abstract}

Another Montenegrin critic Jovan Nikolaidis (2007) "defines the last decades of the twentieth century as being full of lyrical poetry written by men" and that there are not yet any women poets in this sultry area of Montenegrin male vanity:

"But then, a strong and disciplined European-bred sound of new poetry, the voice of a new prose, a view of new literary and film criticism reached us in Montenegrin literature, at first quiet, anxious, and then becoming ever more loud and original; among the gloom and despair there sprang up a literature that was fresh, eloquent and European. "Women's writing" also arrived, and the female "voice" was at last heard in Montenegro. The voices of women poets resounded, and good, strong and interesting poetry was born. Like a phoenix from that macho image of the blinkered world, a mature poetic expression, with the seal of a new sensibility, completely authentic and with a sufficiently theoretical foundation." (2007)

***

Trying to map the female poetic voices and their reflections on their status in the literary canon, I have formulated questions and emailed them to the Montenegrin women authors, belonging to different generations:

What is the status of women poets in contemporary Montenegrin literature? Are women poets in Montenegro left out of literary histories, anthologies and critical reviews? How do you define literary canon: is it a "political construct" or do you consider it void of patriarchal influences? Do you think the creation of a female canon is justified? Should women poets and prose writers in the Montenegrin literary context be considered a separate group in the same way that American women were in one phase in their work (E. Showalter)? What is your attitude towards feminist (literary) theory and criticism and do you think that it can effect a better affirmation of the writing of women authors?

In her answer to these questions Ervina Dabižinović (contemporary Montenegrin activist, poet, novelist, esseyist, lives in Kotor and is a member of feminist organization ANIMA, who advocates the feminist spaces of literature and thinks that they would enrich the culture of Montenegro, causing it to change) emphasizes that women authors in Montenegro are left out and that there is a long history of resistance to the poetic works of women poets in Montenegro. She describes literary canon as a political construct founded on patriarchal thought and culture, adding one more insurmountable difficulty to this issue - it has been monopolized by elites that include or exclude any thought that is inappropriate or disobedient. "The literary canon in Montenegro is 'suffering' from severe illness," Dabižinović adds. She emphasizes also the importance of Gayatri Spivak's strategic essentialism:

"It sounds dangerous, but it is a policy to clearly define for a certain time a female tradition whose aim is to make women more visible and to insert a woman's contribution where its place is in civilization. Not every woman is a feminist, nor is every female poet a feminist poet and that is fine. Not every text written by women is feminist. It is recognized as feminist inasmuch as it has grown out of the politics of feminism and those women who carry it out into public define themselves as advocates of that politics and literature. For me it would be extremely worthwhile for a collection of works by women poets in Montenegro to be made. I would like the culture of Montenegro to open up to this mass of voices because nowadays the modern world and literature is buzzing from the masses. It would be particularly important to me to find a place for those women who speak 'the truth of power to the face' (Shoshana Felman)." (2013)

According to another Montenegrin author Bosiljka Pušić (contemporary Montenegrin novelist and poet, who lives and works in Herceg Novi) the position of women writers in Montenegro today is more than pathetic: 
"Forty years ago, when I published my first book of poetry, editors of literary journals, literary critics, anthologists, commentators on literary happenings in the daily papers were amazingly kind towards the female pen. However, I was for a long time the only female member of the Association of Writers and so that attention was directed exclusively towards me. At that time I found my way into many anthologies, and I was a delegate at many poetry events all over the former Yugoslavia. Today the helm of editing journals and putting together anthologies has been taken by a crew of young males, who to my great astonishment, have closed their ranks and become pretty much an armored bunker which hardly any female literary voice can approach. Maybe the fact that literary criticism has all but died is also to blame. It all boils down to friends writing reviews about friends, and they are of course affirmative, so a critical attitude towards the current vibrant literary trend is non-existent. Without critical discussion there is no highlighting and fair evaluation of what is being published. The situation for women writers in Montenegro is truly more than desperate." (2013)

Considering the issue of feminist literary theory and criticism and its possibility of helping to improve women authors' position, she writes about having for a long resisted the idea that women writing should be separated from male writing, "because we all live under the same sky and struggle with the same problems" (2013). In relation to her own poetics she states that "the themes of my prose works (novels) are not written at all from the aspect of a woman, but from the aspect of a being who lives in the geographical crosswinds exposed to the turbulence of war, where social and historical events model the equally dark destinies of the male and female world. Those who have analyzed my novels have really touched on that as a feature of my poetry and my prose" (2013). Pušic further explaines that since it is evident that male writers do not have the same yardsticks for measuring what women write against what they write themselves, the situation forces the thinking female to rebel in some way, and not with a whisper but with a scream:

"And this means applying everything that has proved to be effective elsewhere in the world, here too in Montenegro. The doors and windows need to be opened up to let fresh air into the room. I do not know how the male writing world would react, although I can make a fairly good guess, if a journal were started which in several languages affirmed EXCLUSIVELY poetry written by women." (2013)

\section{References}

anon., ,Smrt crnogorske Safo," Jugoslavenski list, 16. maj 1940. godine.

Gilbert, Sandra, Susan Gubar, eds., Feminist Literary Theory and Criticism: A Norton Reader, Norton\&Company, New York and London 2007.

Đurić, Dubravka, „Teorijsko-interpretativni modeli u postjugoslovenskim pesničkim kulturama," Sarajevske Sveske br. 32/33, 2011, http://www.sveske.ba/bs/content/teorijsko-interpretativni-modeli-u-postjugoslovenskim-pesnickim-kulturama

Nelević, Nataša, ed., Istorijska čitanka: Žene u Crnoj Gori od 1790. do 1915., NOVA Centar za feminističku kulturu, Podgorica 2011.

Nikolaidis, Jovan, ,"CG poezija CG poetesa”, Sarajevske sveske, br. 15-16, 2007.

Rakočević, Bogić, ed., Poetika Montenegrina: antologija crnogorske poezije XX vijeka, Otvoreni kulturni forum i Nacionalna biblioteka „Đurđe Crnojević," 2012.

Šuvaković, Miško, ,,Mnogostruka lica kanona: KAHOH ili KANONI mnoštvo pitanja sa odgovorima,” Sarajevske Sveske br. 08/09, 2005, http://www.sveske.ba/bs/content/mnogostruka-lica-kanona-kanon-ili-kanoni-mnostvo-pitanja-sa-odgovorima

Ugrešić, Dubravka, ,„Ženski književni kanon," 2012, http://www.6yka.com/novost/24684/dubravka-ugresic-zenski-knjizevni-kanon

Vukčević, Lidija, „Polemično u odnosu na kanon: Antologija „Poetika Montenegrina“ crnogorski poetopis,” 2013, http://www.vijesti.me/kultura/antologija-poetika-montenegrina-crnogorski-poetopis-clanak-124436 